\title{
Effects of ascorbic acid and iron nanoparticles supplements on hyperthermia-induced stress in African catfish, Clarias gariepinus (Burchell, 1822)
}

\author{
Gbadamosi K. Oluyemi* ${ }^{*}$
}

\begin{abstract}
Background: Thermal stressors in tropical aquaculture are unavoidable and cause many harmful effects. This study assessed the effects of ascorbic acid (AA) and iron nanoparticles supplementation in the diet of African catfish, Clarias gariepinus, and exposed to hyperthermia-induced stress. C. gariepinus juveniles weighing $6.89 \pm 0.05 \mathrm{~g}$ were randomly distributed into plastic tanks of $48 \mathrm{~cm}$ by $30 \mathrm{~cm}$ by $31 \mathrm{~cm}$ dimension at ten fish per tank in a triplicate treatment. Five isonitrogenous and isocaloric diets containing $35 \%$ crude protein were formulated with AA and iron nanoparticles supplementation at $(10,8,6,4,0) \mathrm{g} / \mathrm{kg}$ of $A A$ and $(0,4,6,8,0) \mathrm{g} / \mathrm{kg}$ of iron nanoparticles in treatment $1,2,3,4$ and 5 , respectively. After 8 weeks of feeding, fish were exposed to hyperthermia-induced stress. Blood was collected from the fish for haematological and biochemical analyses.

Results: Results showed that there were significant differences $(P<0.05)$ in the growth performance and nutrient utilization of fish subjected to hyperthermia-induced stress. Treatment three had the highest specific growth rate of $1.89 \mathrm{~g}$ per day and the best feed conversion ratio (FCR) of 1.48 .

Conclusion: Mortality was reduced with the supplementation of the fish diets with AA and iron nanoparticles. Based on the result of this study, a supplementation level containing AA and iron nanoparticles supplementation of $6 \mathrm{~g} / \mathrm{kg}$ and $4 \mathrm{~g} / \mathrm{kg}$ were sufficient as a stress-reducing agent in the production of C. gariepinus during hyperthermia stress.
\end{abstract}

Keywords: Hyperthermia, Stress, Ascorbic acid, Iron, Nanoparticles, African catfish, supplement

\section{Background}

Stress in fish is a habitual, undesirable aspect of production. It results from biotic and abiotic challenges that act in changing or modifying the animal's natural or homeostatic state (Tejpal et al., 2009). Stressors in aquaculture are unavoidable and cause many harmful effects. Stress is a major concern in aquaculture as many stressors can predispose the fish to compromise growth, promote disease and ultimately health (Saima et al., 2017). The

\footnotetext{
*Correspondence: okgbadamosi@futa.edu.ng

Department of Fisheries and Aquaculture Technology, Federal University of Technology, Akure, Ondo, Nigeria
}

ability to respond to stress is vital to the survival of any living organism, though sustained reactions can become detrimental to the health and welfare of fishes. Stress responses of vertebrates are known through several studies in their physiological, behavioural and psychological components, under acute and chronic contexts (Leonor \& Rui, 2009).

One of the main challenges in aquaculture is climate and weather conditions that have direct effects on the production and culture of fish, especially in the tropics. Fish are subject to stress from either rapid temperature fluctuations that preclude acclimation or inappropriate water temperature (beyond the high or low range of 
tolerance) (Gbadamosi et al., 2017). Hyperthermia stress can be described as the process whereby the fish are stressed when exposed to extreme temperature or when their water temperature is higher than the optimal tolerance range (Saima et al., 2017). This condition can lead to an increased body temperature due to failed thermoregulation that occurs when a body produces or absorbs more heat than it dissipates. This increase in body temperature is known as psychological stress-induced hyperthermia, which is a basic stress response broadly observed in animals (Naoya et al., 2014). Hyperthermia has been used experimentally as a stressor in challenge studies involving infectious agents, for example in rainbow trout (Oncorhynchus mykiss) exposed to Saprolegnia parasitica (Gieseker et al., 2006).

Iron is one of the most essential micronutrients in terms of its effect on the functioning of the immune system and defence against various infections. Iron is an essential element for blood production and $70 \%$ of the body synthesized irons are found in the red blood cells called haemoglobin and in the muscle cells called myoglobin. Iron deficiency causes immune suppression, growth depression, changes in haematological parameters, susceptibility to diseases, poor food conversion and microcytic anaemia in teleost fish (Adel \& Khara, 2014). Ascorbic acid also known as Vitamin $C$ is a white, crystalline, water-soluble vitamin with the molecular formula $\mathrm{C}_{6} \mathrm{H}_{8} \mathrm{O}_{6}$. It is a powerful enhancer of non-heme iron absorption. Heme iron, derived from haemoglobin and myoglobin, is well absorbed and relatively affected by other food eaten (Lynch \& Cook, 1980). There is a synergy between iron and ascorbic acid, both are antioxidants. Ascorbic acid also known as vitamin $\mathrm{C}$ helps the body of fish to absorb iron at a better rate, while it also plays an important role in synthesizing red blood cells (Gbadamosi, 2006). Vitamin C is very essential in the diets of fish, especially in freshwater fish, because it cannot be synthesized by teleost; this is due to the lack of L-gulonolactone oxidase enzyme which is required to catalyze the conversion of gulonolactone to ascorbic acid (Elbaraasi et al., 2004), and therefore fish requires ascorbic acid in their diets. The body of fish absorbs iron much more effectively when vitamin $C$ is also present. In addition to the absorption factor, vitamin $\mathrm{C}$ also helps to synthesize red blood cells while iron is the main part of haemoglobin found in red blood cells (Adel \& Khara, 2014).

Nanotechnology is a branch of technology that deals with dimensions and tolerances of less than $100 \mathrm{~nm}$; it is the science, engineering and technology conducted at the nanoscale, which is about 1-100 nm (Drexler, 1986, 1992). Iron oxide nanoparticle $\left(\mathrm{Fe}_{2} \mathrm{O}_{3} \mathrm{NPs}\right)$ is not toxic and of great interest due to its unique physicochemical properties (Zhang \& Wei, 2003; Huber, 2005). It has a great potential in biomedical applications, as food additives, antimicrobial additives and as drug carriers due to its super-paramagnetic properties and potential biocompatibility (Huber, 2005). The current study was designed to determine the synergistic effects of ascorbic acid and iron nanoparticles on hyperthermia-induced stress in the aquaculture of African catfish, Clarias gariepinus. The African catfish, C. gariepinus, is the most important fish species cultured in Nigeria; it grows rapidly, disease and stress resistant, sturdy and highly productive in polyculture with many other fish species (FAO, 2019). These species have shown considerable potential as fish suitable for use in intensive aquaculture. It is expected that results from this study will provide a sustainable and environmental friendly method in reducing the adverse effects of stressors in African Catfish aquaculture Furthermore, it will also help to provide the adequate dosage of ascorbic acid (Vitamin C) and iron nanoparticles needed by $C$. gariepinus during hyperthermia stress periods.

\section{Methods \\ Description of the experimental site}

The study was carried out at the Research and Teaching farm of the Department of Fisheries and Aquaculture Technology, Obakekere, Federal University of Technology, Akure, Ondo State, Nigeria.

\section{Preparation of experimental diet}

The feed ingredients including ascorbic acid were purchased at Animal Concept, Akure, Ondo State, while the iron nanoparticles were procured from Cellulyte (Kentucky, USA). Five isonitrogenous diets were formulated to provide $35 \%$ crude protein and designated as T1 (control), T2, T3, T4 and T5 are shown in Table 1. Five ascorbic acid inclusion levels used were $10 \mathrm{~g} / \mathrm{kg}, 8 \mathrm{~g} / \mathrm{kg}, 6 \mathrm{~g} / \mathrm{kg}$, $4 \mathrm{~g} / \mathrm{kg}$ and $0 \mathrm{~g} / \mathrm{kg}$, respectively, while the iron nanoparticles inclusion level used were $(0.00,4.00,6.00,8.00$ and $10.00 \mathrm{~g} / \mathrm{kg}$, respectively.

All dietary ingredients were weighed with a sensitive weighing top balance (Mettler Toledo, PB8001, London). The ingredients were then ground to a small particle size, ingredients, such as iron nanoparticles, vitamin premix and ascorbic acid, were thoroughly mixed in the mixture using the manual turner to obtain a homogenous mixture, and $1 \mathrm{l}$ of hot water was added to gelatinize the mixture and to form uniform dough. Cassava starch was added as a binder. The homogenized feed mixture was then pressed without steam through a mincer attached to the Hobart A-200 T pelleting machine using a $2 \mathrm{~mm}$ diameter die. After pelleting, the feeds were immediately sun-dried for $72 \mathrm{~h}$ at ambient temperature of $27-30{ }^{\circ} \mathrm{C}$ and air-dried. After drying, the diets were sieved and 
Table 1 Composition of the experimental diet in $\mathrm{g} / 100 \mathrm{~g}$ dry matter containing various inclusion levels of ascorbic acid and iron nanoparticles for C. gariepinus

\begin{tabular}{|c|c|c|c|c|c|}
\hline & \multicolumn{5}{|l|}{ Treatments } \\
\hline & T1 (Control) & $\mathrm{T} 2$ & T3 & T4 & T5 \\
\hline \multicolumn{6}{|l|}{ Ingredients } \\
\hline Fish meal (72\%) & 29.00 & 29.00 & 29.00 & 29.00 & 29.00 \\
\hline Yellow maize (10\%) & 18.50 & 18.50 & 18.50 & 18.50 & 18.50 \\
\hline Soybean meal (42\%) & 29.00 & 29.00 & 29.00 & 29.00 & 29.00 \\
\hline Rice bran (12\%) & 12.50 & 12.50 & 12.50 & 12.50 & 12.50 \\
\hline Soybean oil & 6.00 & 6.00 & 6.00 & 6.00 & 6.00 \\
\hline Vit. / min. premix & 2.00 & 2.00 & 2.00 & 2.00 & 2.00 \\
\hline Cassava Starch & 2.00 & 2.00 & 2.00 & 2.00 & 2.00 \\
\hline Ascorbic acid & 1.00 & 0.80 & 0.60 & 0.40 & 0.00 \\
\hline Iron nanoparticles & 0.00 & 0.20 & 0.40 & 0.60 & 1.00 \\
\hline \multicolumn{6}{|l|}{ Parameters (\%) } \\
\hline Moisture & $19.39 \pm 0.05^{\mathrm{a}}$ & $10.19 \pm 0.17^{e}$ & $10.83 \pm 0.10^{d}$ & $18.42 \pm 0.09^{b}$ & $11.62 \pm 0.09^{c}$ \\
\hline Ash & $7.16 \pm 0.08^{e}$ & $17.83 \pm 0.12^{b}$ & $10.51 \pm 0.10^{d}$ & $14.31 \pm 0.06^{c}$ & $20.60 \pm 0.09^{a}$ \\
\hline Lipid & $3.92 \pm 0.04^{b}$ & $3.32 \pm 0.10^{d}$ & $3.69 \pm 0.08^{b c}$ & $3.67 \pm 0.03^{c}$ & $4.76 \pm 0.08^{\mathrm{a}}$ \\
\hline Crude Protein & $35.01 \pm 0.08^{a}$ & $34.95 \pm 0.12^{b}$ & $35.05 \pm 0.14^{a}$ & $35.09 \pm 0.06^{\mathrm{a}}$ & $35.06 \pm 0.06^{\mathrm{a}}$ \\
\hline Crude Fibre & $5.02 \pm 0.13^{d}$ & $6.70 \pm 0.07^{\mathrm{a}}$ & $4.59 \pm 0.08^{e}$ & $5.42 \pm 0.04^{c}$ & $5.85 \pm 0.05^{b}$ \\
\hline NFE & $24.49 \pm 0.12^{c}$ & $29.11 \pm 0.12^{b}$ & $33.78 \pm 0.12^{\mathrm{a}}$ & $23.09 \pm 0.10^{d}$ & $22.11 \pm 0.15^{\mathrm{e}}$ \\
\hline
\end{tabular}

Nitrogen free extract (NFE) as calculated as 100 - (crude protein + moisture + ether extract + ash + crude fibre)

Figures in each column with the same superscripts are not significantly different $(P>0.05)$

Vitamin and mineral premix-Each 1 kg feed contains vitamin A,1000 mg; vit., D2, 8 mg; vit. E, 7.0 g; vit. K, 0.8 g; vit. B1, 0.49 g, vit. B2, 1.6 g; vit B6 0.6 g; vit. B12 4 mg; Pantothenic acid 49; Nicotinic acid 8 g; Folic acid, 400 mg; Biotin, 20 mg; vit C 40 g; Choline chloride, 200 mg; Copper, 4.0 g; lodine,0.4 g; Iron, 12 mg; Manganese, 22 g; Zinc $22 \mathrm{~g}$ and Selenium $0.04 \mathrm{~g}$ - BiotinM, UK

Mean in a given row with the same letter $a, b, c, d$ or e were not significantly different at $(P>0.05)$

stored prior to the start of the feeding trial. Standard and official methods (AOAC, 2010) were used to carry out the proximate analyses of the experimental diets in the study.

\section{Experimental fish and feeding trial}

Clarias gariepinus juveniles were procured and acclimated for 2 weeks at the Fisheries and Aquaculture Research and Teaching farm, Obakekere, Federal University of Technology Akure, Ondo State, Nigeria. Fish were not fed $24 \mathrm{~h}$ prior to the feeding trial in order to maintain a uniform stomach condition of the fish. Each experimental diet was fed to the fish in triplicates of the six treatments for 8 weeks (56 days) between February and March, 2017. Fish were then fed at $5 \%$ body weight per day at the first week and the weight was later adjusted biweekly. Growth of fish was monitored biweekly by batch weighing of fish from each tank. The fish were distributed randomly into 15 rectangular plastic tanks of the dimension $(48 \mathrm{~cm}$ by $30 \mathrm{~cm}$ by $31 \mathrm{~cm}$ ) at 10 fish per tank.

\section{Ethical approval from ethics committee}

The African catfish, C. gariepinus, used for the study were humanely handled in accordance with the ethics and regulation guiding the use of research animals as approved by the Federal University of Technology, Akure (FUTA) Nigeria, and in accordance with the Code of Ethics of the standard procedure of the Home Office Regulations as stipulated by the Animal Scientific Procedures Acts of 1986, United Kingdom.

\section{Water quality parameters}

Temperature and dissolved oxygen were monitored using Multiparameter YSI Model 57 water checker. Hydrogen ion concentration $(\mathrm{pH})$ was also monitored using $\mathrm{pH}$ meter YSI Model 57. Conductivity was also monitored using conductivity meter YSI Model 57.

\section{Hyperthermia-induced stress}

At the end of the feeding trial, 150 fish previously fed each experimental diet from each treatment representing 30 fish per treatment were kept in plastic tanks for hyperthermia-induced stress according to a modified method of Sen et al. (2014) using a 2-kW heating rod (Binatone, Japan). The temperature in treatments was based on a pilot study where the sub-lethal temperature of $<32{ }^{\circ} \mathrm{C}$ was recorded for C. gariepinus. The rate of heating ramp was about $3^{\circ} \mathrm{C} / \mathrm{h}$. Water temperature was maintained at 
$32 \pm 0.5{ }^{\circ} \mathrm{C}$ throughout the hyperthermia-induced stress period. No fish died during the hyperthermia treatment. Two fish were taken randomly at $2 \mathrm{~h}$ after exposure from the tanks. Blood samples were collected via caudal vein puncture immediately after hyperthermia-induced stress from fish for further analyses.

\section{Proximate composition analysis}

The standard method of AOAC (2010) was used to carry out the proximate analysis of air-dried feed samples and fish before the experiment. At the end of the feeding trial, three samples from each treatment and replicates were analysed for proximate composition.

\section{Growth performance evaluation}

Fish performance during the experiment was based on the productivity indices on growth performance and nutrient utilization efficiencies as described by Fasakin et al. (2003) as follows:

\section{Total feed intake}

This was estimated by adding up the weekly feed intakes during the experimental period. The feed Intake was 5\% of body weight $\times$ Number of experimental days.

\section{Total weight gain}

This represents the difference between the initial weight and final weight gained.

$$
\text { Total weight gain }=\text { Final weight }- \text { Initial weight }
$$

\section{Specific growth rate}

Specific Growth Rate (SGR) was calculated from the relationship of the differences in the weight gain of fish within an experimental period. This is calculated as

$$
\begin{aligned}
\text { SGR }(\%)= & \left(\log _{\mathrm{e}} \text { Final weight }-\log _{\mathrm{e}} \text { Initial weight }\right) / \\
& \text { Number of feeding days }(56 \text { days }) \times 100
\end{aligned}
$$

\section{Feed conversion ratio}

Feed Conversion Ratio was calculated as:

$$
\text { FCR }=\text { Total feed consumed / Weight gain }
$$

\section{Protein efficiency ratio}

$$
\text { PER }=\text { Fish weight gain /Protein gain }
$$

where

$$
\text { protein gain }=(\% \text { Protein } \times \text { total diet consumed }) / 100
$$

\section{Survival Rate}

This is calculated as

$$
\begin{aligned}
& \text { (Total number of fish }- \text { Mortality) } / \\
& \text { Total number of fish } \times 100
\end{aligned}
$$

\section{Fish blood analysis}

The blood was collected using sterilized 5-ml heparinized syringes and ethylene-di-amine tetra-acetic acid (EDTA) as anti-coagulant. The syringe was used to draw blood from the fish by injecting it on the ventral midline between the anal opening and the beginning of the anal fin to assess the caudal vein beneath the vertebral column. The blood was stored at $-4{ }^{\circ} \mathrm{C}$ in the refrigerator prior to analysis. The blood analysis followed the method described by Svobodova et al. (1991).

\section{Blood cell counts}

Red blood cells (RBC) were estimated using a Neubauer haematocytometer with (Natt-Herrick) diluting fluid for RBC counts. Haemocytometer consists of a counting chamber, a cover slip, white and red blood cell pipette and a plastic mouthpiece for drawing the fluid into pipette. The total leukocyte counts (WBC) were determined with a Neubauer haematocytometer using Rees diluting solution. To obtain the differential counts of leukocytes, that is, the number of Lymphocytes, Neutrophil, Eosinophils and Monocytes, the prepared blood smears were first airdried, fixed in $96 \%$ ethanol for $30 \mathrm{~min}$, stained by Giemsa staining solution for $30 \mathrm{~min}$ and were examined under light microscope.

$$
\begin{aligned}
\mathrm{RBC}(\text { Erythrocyte count })= & \text { No. of cells counted } \times 5 \\
& \times 10 \times 200\left(10^{6} \mathrm{~mm}^{3}\right)
\end{aligned}
$$

\section{Biochemical analysis}

Blood was centrifuged at $3000 \mathrm{rpm}$ for $15 \mathrm{~min}$ in a cooling centrifuge for separation of plasma which was stored at $-18{ }^{\circ} \mathrm{C}$ prior to biochemical analysis. The Serum total protein was measured according to the method of Grant et al. (1987). The serum albumin level was estimated according to the method of Doumas et al. (1981). The serum globulin was calculated by subtracting the total protein from the albumin as described by Doumas et al. (1981). Serum glucose concentration was measured according to Hardy and Sullivan (2003) using Bio-La-Test oxochrome GLUCOSA (Glu 250E). Based on the oxidation of glucose catalyzed by glucose oxidase to hydrogen peroxide and gluconate. The peroxide produced was 
determined by oxidation coupling with substituted phenol and 4-amino antipyrin. The coupling was catalyzed by peroxidase.

\section{Statistical analysis}

Experimental results were subjected to one-way Analysis of Variance (ANOVA) test and significant difference $(P>0.05)$ among means using SPSS 22 (Statistical Package for Social Sciences). Differences were considered significant at $(P$-levels $<0.05)$ using Duncan's new multiple range tests.

\section{Results}

\section{Water quality parameters}

The results of water quality parameters, such as Temperature, Dissolved oxygen, $\mathrm{pH}$ and conductivity, monitored during the experiment are presented in Table 2 . The conductivity ranges from $291.83 \pm 3.25 \mathrm{~S} / \mathrm{m}$ in treatment 1 to $324.50 \pm 6.64 \mathrm{~S} / \mathrm{m}$ as the highest in treatment 5 . The $\mathrm{pH}$ values range from $6.37 \pm 0.12$ in treatment 2 to $6.55 \pm 0.05$ in treatment 5 . The dissolved oxygen ranges from 6.13 to $7.05 \mathrm{mg} / \mathrm{l}$. During the experiment, the fish were cultured under a temperature range of $27.33 \pm 0.10$ $27.62 \pm 0.16{ }^{\circ} \mathrm{C}$. Dissolved oxygen content ranges from 6.13 to $7.05 \mathrm{mg} / \mathrm{l}$.

\section{Proximate composition of the experimental feed and fish} The results of the analysis of the proximate composition of the experimental feed containing varying inclusion level of ascorbic acid and iron nanoparticles as additives showed that the diet is isonitrogenous (Table 1). There are significant differences in all other proximate composition parameters in the experimental feeds used during the feeding trial. The initial and final carcass analyses of the proximate composition of the experimental fish before and after the experiment are presented in Table 3. The result showed that the crude protein in the initial experimental fish was $60.77 \pm 0.13 \%$. The moisture content in the initial experimental fish was $14.62 \%$, while the highest moisture content in the final experimental fish was $13.80 \%$ in $\mathrm{T} 1$ and the lowest in $\mathrm{T} 4$ as $10.21 \%$. Ash in the initial experimental fish was $10.06 \%$, while in the final experimental fish, T4 had the highest ash content as $15.33 \%$ and the lowest was recorded in $\mathrm{T} 1$ as $11.31 \%$.

\section{Growth performance and nutrient utilization of Clarias gariepinus fed ascorbic acid and iron nanoparticles}

The results of growth performance and nutrient utilization of C. gariepinus fed varying levels of ascorbic acid and iron nanoparticles are shown in Table 4. After the feeding trials, fish fed with Diet 3 shows the highest percentage weight gain of $387.45 \pm 11.88 \%$ and specific

Table 2 Water Quality parameters in the culture tanks

\begin{tabular}{lrrrrrr}
\hline Parameters & \multicolumn{1}{l}{ Treatment } & & & & ANOVA P value \\
\cline { 2 - 5 } & \multicolumn{1}{c}{ T1 (control) } & \multicolumn{1}{c}{ T2 } & \multicolumn{1}{c}{ T3 } & \multicolumn{1}{c}{ T4 } & T5 & \\
\hline Temperature $\left({ }^{\circ} \mathrm{C}\right)$ & $27.43 \pm 0.36^{\mathrm{a}}$ & $27.58 \pm 0.22^{\mathrm{a}}$ & $27.33 \pm 0.10^{\mathrm{a}}$ & $27.62 \pm 0.16^{\mathrm{a}}$ & $27.58 \pm 0.19^{\mathrm{a}}$ & 0.87 \\
Dissolved oxygen $(\mathrm{mg} / \mathrm{l})$ & $7.05 \pm 0.19^{\mathrm{a}}$ & $6.88 \pm 0.56^{\mathrm{a}}$ & $6.15 \pm 0.82^{\mathrm{a}}$ & $7.00 \pm 0.38^{\mathrm{a}}$ & $6.13 \pm 0.64^{\mathrm{a}}$ & 0.63 \\
$\mathrm{pH}$ & $6.47 \pm 0.11^{\mathrm{a}}$ & $6.37 \pm 0.12^{\mathrm{a}}$ & $6.50 \pm 0.05^{\mathrm{a}}$ & $6.47 \pm 0.03^{\mathrm{a}}$ & $6.55 \pm 0.05^{\mathrm{a}}$ & 0.62 \\
Conductivity $(\mathrm{S} / \mathrm{m})$ & $291.83 \pm 3.25^{\mathrm{a}}$ & $303.17 \pm 8.77^{\mathrm{a}}$ & $300.50 \pm 26.08^{\mathrm{a}}$ & $283.67 \pm 27.38^{\mathrm{a}}$ & $324.50 \pm 6.64^{\mathrm{a}}$ & 0.75 \\
\hline
\end{tabular}

Figures in each row having the same superscripts are not significantly different $(P>0.05)$

Mean in a given row with the same letter a, b, c, d or e were not significantly different at $(P>0.05)$

Table 3 Proximate composition (\%) of the carcass of Clarias gariepinus

\begin{tabular}{|c|c|c|c|c|c|c|}
\hline \multirow[t]{2}{*}{ Parameters (\%) } & \multirow[t]{2}{*}{ Sample initial (\%) } & \multicolumn{5}{|c|}{ Final sample of fish } \\
\hline & & T1 (Control) & T2 & T3 & T4 & T5 \\
\hline Moisture & $14.62 \pm 0.11^{\mathrm{a}}$ & $13.80 \pm 0.09^{b}$ & $12.82 \pm 0.03^{c}$ & $10.93 \pm 0.04^{e}$ & $10.21 \pm 0.02^{e}$ & $11.20 \pm 0.05^{\mathrm{d}}$ \\
\hline Ash & $10.06 \pm 0.08^{e}$ & $11.31 \pm 0.12^{d}$ & $13.20 \pm 0.05^{c}$ & $13.38 \pm 0.07^{c}$ & $15.33 \pm 0.03^{\mathrm{a}}$ & $14.33 \pm 0.05^{b}$ \\
\hline Fat/lipid & $13.73 \pm 0.08^{\mathrm{a}}$ & $11.98 \pm 0.10^{c}$ & $13.18 \pm 0.05^{b}$ & $11.65 \pm 0.08^{d}$ & $10.75 \pm 0.04^{e}$ & $10.32 \pm 0.07^{f}$ \\
\hline Crude protein & $60.77 \pm 0.13^{c}$ & $62.73 \pm 0.10^{b}$ & $60.01 \pm 0.08^{d}$ & $63.91 \pm 0.05^{\mathrm{a}}$ & $63.00 \pm 0.09^{b}$ & $63.73 \pm 0.09^{a}$ \\
\hline NFE & $0.81 \pm 0.08^{\mathrm{a}}$ & $0.17 \pm 0.03^{c}$ & $0.79 \pm 0.12^{\mathrm{a}}$ & $0.67 \pm 0.17^{a}$ & $0.71 \pm 0.01^{\mathrm{a}}$ & $0.41 \pm 0.02^{b}$ \\
\hline
\end{tabular}

Nitrogen free extract (NFE) as calculated as 100 - (crude protein + moisture + ether extract + ash + crude fibre)

Figures in each column having the same superscripts are not significantly different $(P>0.05)$

Mean in a given row with the same letter $a, b, c$, d or e were not significantly different at $(P>0.05)$ 
Table 4 Growth performance and nutrient utilization of Clarias gariepinus

\begin{tabular}{|c|c|c|c|c|c|c|}
\hline Parameters & T1 (Control) & $\mathrm{T} 2$ & T3 & T4 & T5 & ANOVA $P$ value \\
\hline Initial weight (g) & $6.09 \pm 4.64^{\mathrm{a}}$ & $5.61 \pm 0.55^{\mathrm{a}}$ & $6.34 \pm 3.40^{\mathrm{a}}$ & $5.91 \pm 3.45^{\mathrm{a}}$ & $6.04 \pm 3.52^{\mathrm{a}}$ & 0.60 \\
\hline Final weight (g) & $14.38 \pm 10.42^{b c}$ & $13.79 \pm 13.24^{\mathrm{cd}}$ & $19.50 \pm 10.35^{a}$ & $16.26 \pm 8.66^{d}$ & $15.90 \pm 6.26^{b}$ & 0.00 \\
\hline Weight gain (g) & $8.29 \pm 0.63^{b c}$ & $8.18 \pm 0.69^{c d}$ & $13.16 \pm 0.19^{a}$ & $10.35 \pm 0.76^{d}$ & $9.86 \pm 0.34^{b}$ & 0.00 \\
\hline Daily feed intake (g/day) & $3.81 \pm 0.31^{b}$ & $3.23 \pm 0.12^{b}$ & $4.77 \pm 0.23^{a}$ & $3.99 \pm 0.28^{b}$ & $3.94 \pm 0.21^{b}$ & 0.01 \\
\hline Protein intake (g) & $9.33 \pm 6.17^{b}$ & $9.55 \pm 2.46^{b}$ & $10.06 \pm 4.42^{b}$ & $11.05 \pm 5.54^{\mathrm{a}}$ & $9.79 \pm 4.07^{b}$ & 0.01 \\
\hline PER & $2.36 \pm 0.08^{\mathrm{ab}}$ & $2.33 \pm 0.14^{\mathrm{ab}}$ & $2.61 \pm 0.06^{\mathrm{a}}$ & $2.16 \pm 0.15^{b}$ & $2.43 \pm 0.10^{\mathrm{ab}}$ & 0.01 \\
\hline FCR & $1.86 \pm 0.09^{a b c}$ & $2.02 \pm 0.20^{\mathrm{ab}}$ & $1.48 \pm 0.48^{c}$ & $2.35 \pm 0.25^{\mathrm{a}}$ & $1.74 \pm 0.08^{b c}$ & 0.03 \\
\hline$S G R$ & $1.13 \pm 0.08^{b c}$ & $0.85 \pm 0 \mathrm{~s} .23^{\mathrm{cd}}$ & $1.89 \pm 0.75^{\mathrm{a}}$ & $0.51 \pm 0.13^{d}$ & $1.33 \pm 0.05^{b}$ & 0.00 \\
\hline$\%$ Survival rate & $80.00 \pm 0.00^{b}$ & $80.07 \pm 3.33^{b}$ & $93.33 \pm 3.33^{\mathrm{a}}$ & $80.00 \pm 5.77^{b}$ & $80.00 \pm 5.77^{b}$ & 0.00 \\
\hline
\end{tabular}

Figures in each row having the same superscripts are not significantly different $(P>0.05)$

Mean in a given row with the same letter $a, b, c, d$ or e were not significantly different at $(P>0.05)$

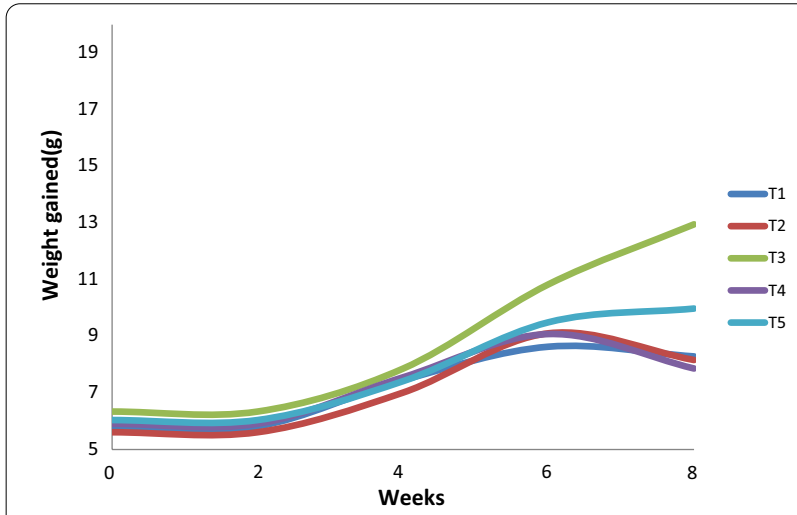

Fig. 1 Weight gain pattern of C. gariepinus fed with varying levels of ascorbic acid and iron nanoparticles

growth rate of $1.89 \pm 0.75 \%$, respectively. Fish fed with Diet 5 without ascorbic acid supplementation but with $10 \mathrm{~g} / \mathrm{kg}$ of iron nanoparticles also show a significant specific growth rate of $1.33 \pm 0.05 \%$ and percentage weight gain of $310.85 \pm 5.16 \%$. Feed conversion ratio was highest in treatment 4 which was $2.35 \pm 0.25$ and least in T3 with $1.48 \pm 0.48$. Protein efficiency ratio also shows a significant difference $\mathrm{P}<0.05$ with the highest recorded in fish fed Diet 3 as $2.61 \pm 0.06$ and lowest in fish fed with diet 4. Fish in treatment 3 had the highest weight gain. The lowest mortality was recorded in treatment 3 which also recorded the highest survival rate of $93.33 \pm 3.33 \%$.

The weight gain pattern of C. gariepinus fed with varying levels of ascorbic acid and iron nanoparticles is illustrated in Fig. 1. Fish fed Diet 3 had significantly better progressive weight gain pattern than fish in the remaining treatments.

\section{Haematological parameters of C. gariepinus after hyperthermia-induced stress}

The basic haematological indices analysed in the African Catfish, Clarias gariepinus, fed with the experimental diet are shown in Table 5. The highest Red blood cells count was recorded for fish fed with Diet 2 as $3.85 \pm 0.03$ and the lowest was recorded in fish fed with diet 5 as $1.90 \pm 0.00$. The red blood cell count was significantly different across the treatments. Lymphocyte count in blood

Table 5 Haematological parameters of fish fed ascorbic acid and iron nanoparticles after being subjected to hyperthermia-induced stress

\begin{tabular}{llllll}
\hline Treatments & \multicolumn{3}{l}{ Total differential count } & & \\
\cline { 2 - 6 } & RBC $\times \mathbf{1 0}^{\mathbf{6}} \mathbf{m m}^{-\mathbf{3}}$ & Neutrophils (\%) & Lymphocytes (\%) & Monocytes (\%) & Eosinophil (\%) \\
\hline T1 & $2.75 \pm 0.03^{\mathrm{d}}$ & $64.02 \pm 0.04^{\mathrm{b}}$ & $30.02 \pm 0.04^{\mathrm{d}}$ & $3.02 \pm 0.04^{\mathrm{a}}$ & $3.02 \pm 0.04^{\mathrm{a}}$ \\
T2 & $3.85 \pm 0.03^{\mathrm{a}}$ & $58.02 \pm 0.04^{\mathrm{d}}$ & $41.02 \pm 0.04^{\mathrm{b}}$ & $1.00 \pm 0.05^{\mathrm{c}}$ & $\mathrm{ND}$ \\
T3 & $2.95 \pm 0.03^{\mathrm{c}}$ & $52.99 \pm 0.04^{\mathrm{e}}$ & $43.01 \pm 0.02^{\mathrm{a}}$ & $1.68 \pm 0.37^{\mathrm{b}}$ & $2.00 \pm 0.02^{\mathrm{b}}$ \\
T4 & $3.32 \pm 0.04^{\mathrm{b}}$ & $60.00 \pm 0.03^{\mathrm{c}}$ & $40.02 \pm 0.04^{\mathrm{c}}$ & $\mathrm{ND}$ & $\mathrm{ND}$ \\
T5 & $1.90 \pm 0.00^{\mathrm{e}}$ & $76.02 \pm 0.04^{\mathrm{a}}$ & $18.02 \pm 0.04^{\mathrm{e}}$ & $3.00 \pm 0.03^{\mathrm{a}}$ & $3.00 \pm 0.03^{\mathrm{a}}$ \\
ANOVA P value & 0.00 & 0.00 & 0.00 & 0.00 & 0.00 \\
\hline
\end{tabular}

Figures in each column having the same superscripts are not significantly different at $P>0.05$

Mean in a given row with the same letter $a, b, c, d$ or e were not significantly different at $(P>0.05)$

ND Not detected 
Table 6 Basic biochemical parameters of fish subjected to hyperthermia-induced stress

\begin{tabular}{lllllll}
\hline Parameters & \multicolumn{1}{l}{ Treatment } & & & & ANOVA P value \\
\cline { 2 - 6 } & T1 (control) & T2 & T3 & T4 & T5 & 0.00 \\
\hline Total protein (mg/dl) & $1.88 \pm 0.02^{\mathrm{a}}$ & $0.92 \pm 0.04^{\mathrm{c}}$ & $0.94 \pm 0.03^{\mathrm{c}}$ & $1.54 \pm 0.03^{\mathrm{b}}$ & $0.50 \pm 0.05^{\mathrm{d}}$ & 0.00 \\
Albumin $(\mathrm{mg} / \mathrm{dl})$ & $8.07 \pm 0.04^{\mathrm{b}}$ & $6.42 \pm 0.04^{\mathrm{d}}$ & $6.87 \pm 0.03^{\mathrm{c}}$ & $8.68 \pm 0.04^{\mathrm{a}}$ & $4.71 \pm 0.07^{\mathrm{e}}$ & 0.00 \\
Globulin $(\mathrm{mg} / \mathrm{dl})$ & $6.23 \pm 0.09^{\mathrm{b}}$ & $5.49 \pm 0.05^{\mathrm{d}}$ & $5.92 \pm 0.04^{\mathrm{c}}$ & $7.16 \pm 0.04^{\mathrm{a}}$ & $4.23 \pm 0.04^{\mathrm{e}}$ & 0.00 \\
Glucose $(\mathrm{mg} / \mathrm{dl})$ & $49.22 \pm 0.07^{\mathrm{a}}$ & $47.22 \pm 0.05^{\mathrm{d}}$ & $40.51 \pm 0.04^{\mathrm{c}}$ & $43.70 \pm 0.09^{\mathrm{b}}$ & $47.60 \pm 0.05^{\mathrm{a}}$ & 0.00 \\
\hline
\end{tabular}

Figures in each column having the same superscripts are not significantly different at $P>0.05$

Mean in a given row with the same letter $a, b, c, d$ or e were not significantly different at $(P>0.05)$

collected from fish fed diet T3 has the highest percentage count of $43.01 \pm 0.02$. The highest monocyte and eosinophil count was recorded in fish fed Diet 1 as $3.00 \pm 0.03 \%$ and the same variation was also recorded for fish Diet 5 .

\section{Blood biochemical analysis of C. gariepinus after hyperthermia-induced stress}

The result of the biochemical analysis carried out on the fish fed the experimental diet after hyperthermiainduced stress gain is shown in Table 6. The highest total protein was recorded in fish fed with Diet 1 as $1.54 \mathrm{mg} /$ dl followed by fish fed diet 4, 3, 2 and 5 in descending order. However, there was a significant difference in all the blood biochemical parameters level at $P>0.05$ with fish fed Diet 3 recording the lowest glucose level. The serum peroxidase activity was found highest in fish fed with Diet 1 which is the control experiment, followed by significant decrease in 4, 3, 2 and 1 in descending order, respectively.

\section{Discussion}

The water quality parameters recorded during this experimental period are within the optimum range for fish growth and performance according to the ranges recommended for Clariid fish by Boyd (1986). C. gariepinus is a hardy fish but also requires optimum level of water quality parameters for optimum survival, growth and reproduction. The best specific growth rate in the current study is recorded in fish fed Diet 3 containing ascorbic acid and iron nanoparticles supplementation of $6 \mathrm{~g} / \mathrm{kg}$ and $4 \mathrm{~g} / \mathrm{kg}$, respectively. This result is similar to the SGR reported by Baker and Davies (1997) for seabream Chrysophyrs major fed pyridoxine supplemented diet. The result also revealed that fish fed Diet 3 had the highest weight gain. This can be attributed to the ascorbic acid and iron nanoparticles supplementation of $6 \mathrm{~g} /$ $\mathrm{kg}$ and $4 \mathrm{~g} / \mathrm{kg}$, respectively. In agreement with this result, Adel and Khara (2014) reported that the body of fish absorbs iron much more effectively when vitamin $C$ is also present; hence the better growth performance by $C$. gariepinus in this study could be attributed the synergy between the supplemented ascorbic acid and iron nanoparticles. There was significantly better FCR and PER in fish fed with Diet 3 compared to the control. This is in concordance with the better nutrient utilization reported by Gbadamosi et al., (2017) in African catfish, C. gariepinus fed Moringa supplemented diets and subjected to hyperthermia-induced stress. Furthermore, the enhanced growth performance and feed utilization obtained in the current study maybe also due to the complementary effects of the nano-sized iron particles that were easily taken up and utilized in the fish system by boosting the bioavailability and are more effective than at lower doses. The highest survival rate was also recorded in T3; this may be attributed to the synergy of ascorbic acid and iron nanoparticles in the diets of C. gariepinus which ameliorated the effects of hyperthermia-induced mortality.

The present study also revealed that the lowest red blood cell count (RBC) was recorded in fish fed diet T5 without AA supplementation. This correlates with the report of Gbadamosi (2006) which recorded that fish fed without AA supplementation has the lowest RBC. This could be due to the reduction in the absorption and distribution of iron which leads to a reduction in the synthesis of the red blood pigment called haemoglobin. The low value of RBC in the control could be as a result of no inclusion level of iron nanoparticles which helps in production and distribution of red blood cells. In addition, vitamin $\mathrm{C}$ also helps in synthesizing red blood cells while iron is the main part of haemoglobin found in red blood cells (Adel \& Khara, 2014). These low values agree with Aletor and Egberongbe (1998) who stated that red blood cell (RBC) and packed cell volume (PCV) are mostly affected by dietary treatment. Furthermore, differences in blood parameters could be attributed to differences in diets composition as stated by Elbaraasi et al., (2004). The highest lymphocyte count was recorded in fish fed Diet 3 followed by diet 2, 4, 1 and 5, respectively. This can be attributed to the inclusion of ascorbic acid and iron nanoparticles in the diets which helps in the production of white blood cells which helps to fight against infection and acts as anti-stressor. 
Significant better blood biochemical parameters levels were recorded in fish fed diets containing ascorbic acid and iron nanoparticles supplementation. The lowest glucose level was recorded in treatment 3 where fish were fed ascorbic acid and iron nanoparticles supplementation of $6 \mathrm{~g} / \mathrm{kg}$ and $4 \mathrm{~g} / \mathrm{kg}$, respectively. The result of the biochemical parameters of the fish blood could be attributed to the anti-oxidative ability of ascorbic acid and the synergy between ascorbic acid and iron nanoparticles supplemented in fish feed in the current experiment. This synergistic relationship enhanced the ameliorative effects of the experimental feed in combating the effects of reactive oxygen species released during thermal stress condition in aquaculture. The reduction in the level of the physiological stress biomarkers was attributed to the ability of antioxidants like ascorbic acid in reducing or preventing the release of cortisol to the bloodstream of the fish. In concordance, Tekle et al. (2015) reported that the supplementation of phytogenic antioxidants blocked the activation of the hypothalamic-pituitary-interrenal (HPI) axis associated with stressors and thus decreased or prevented the release of the stress hormone cortisol to the bloodstream of O. niloticus subjected to A. hydrophilainduced stress. The decrease in the glucose content of the blood of fish in the current study is in agreement with the decreased level of glucose reported by Gbadamosi et al., (2017) in C. gariepinus fed Moringa supplemented after hyperthermia-induced stress. According to Barton and Iwama (2005) this observation is traceable to the hypoglycaemic activity of the supplement in the enhancement of peripheral metabolism of glucose. However, the highest glucose, globulin and albumin levels were found in the control group.

\section{Conclusions}

The result of this study confirmed the efficacy of ascorbic acid (AA) and Iron nanoparticles $\left(\mathrm{Fe}_{2} \mathrm{O}_{3} \mathrm{NPs}\right)$ as essential nutritional elements and powerful antioxidants in the diet of African catfish C. gariepinus in promoting optimal survival and normal growth performance, especially during episodes of hyperthermia-related stress. Merchie et al. (1997) also suggested that a higher requirement of Vitamin $C$ is necessary during metamorphosis, which is a stressful and physiologically sensitive period as the animals undergo drastic morphological and biochemical changes. Furthermore, the result in this study also proved that the inclusion of iron oxide nanoparticles in the diets of C. gariepinus facilitates absorption of iron and there is also a significant improvement in the growth, survival, nutrient utilization, biochemical parameters and haematological profile of fish fed ascorbic acid supplementation of $6 \mathrm{~g} / \mathrm{kg}$ and $4 \mathrm{~g} / \mathrm{kg}$ of iron nanoparticles when subjected to hyperthermia-induced stress. In all the treatments when compared, C. gariepinus fed with $6 \mathrm{~g} / \mathrm{kg}$ and $4 \mathrm{~g} /$ $\mathrm{kg}$ of ascorbic acid and iron nanoparticles supplementation, respectively, had the best utilization of feed, growth, basic haematological profiles and biochemical parameters when subjected to hyperthermia-induced stress. The synergy between ascorbic acid and iron nanoparticles may be responsible for ameliorating the effects of thermal stress in African catfish C. gariepinus. Moreover, ascorbic acid (AA) and iron are available technically and economically as they form major part of the vitamin-mineral premix commonly used in aquafeed while the use of iron nanoparticles $\left(\mathrm{Fe}_{2} \mathrm{O}_{3} \mathrm{NPs}\right)$ though novel, has the potential to improve aquafeeds, making them healthier and more nutritious with a view towards the production of new sustainable and efficient aquafeed products.

\section{Acknowledgements}

The author is grateful to the Fisheries and Aquaculture Teaching and Research farm, Obakekere, Federal University of Technology, Akure, Ondo State, Nigeria, for providing the fish and space for the feeding trials.

\section{Authors' contributions \\ OKG suggested, planned, and designed the study; performed the data analy- sis; and wrote and edited the manuscript. OKG also wrote the manuscript, corrected and approved the final manuscript. \\ Funding \\ Not applicable. \\ Availability of data and materials \\ Data will not be shared, only by request from the corresponding author. \\ Declarations \\ Ethics approval and consent to participate \\ The African catfish used for the study were humanely handled in accord- ance with the ethics and regulation guiding the use of research animals as approved by the university and in accordance with the Code of Ethics of the standard procedure of the Home Office Regulations as stipulated by the Animal Scientific Procedures Acts of 1986, United Kingdom.}

Consent for publication

Not applicable.

\section{Competing interests}

The author declares that they have no competing interests.

Received: 25 March 2020 Accepted: 31 October 2021

Published online: 07 November 2021

\section{References}

Adel, A., \& Khara, H. (2014). The effects of different dietary vitamin C and iron levels on the growth, hematological and immunological parameters of rainbow trout Oncorhynchus mykiss fingerlings. Iranian Journal of Fisheries Sciences, 15(2), 886-897.

Aletor, V. A., \& Egberongbe, O. (1998). Feeding differently processed soybean and haematological indices in the chicken diet. Journal of Poultry Sciences, 3, 34-36.

AOAC. (2010). Official methods of analysis. Association of Official Analytical chemists.

Baker, R. T. M., \& Davies, S. J. (1997). The quantitative requirement for $\infty$-tocopherol by juvenile African catfish, Clarias gariepinus, Burchell. Animal Science, 65, 135-142 
Boyd, C. E. (1986). Water quality in warm water fish ponds (p. 35). Aubum University.

Doumas, B. T., Bayso, D. D., Carter, R. J., Peter, T., \& Schaffer, R. (1981). Determination of Serum albumin. Clinical Chemistry, 1981(27), 1642.

Drexler, K. E. (1986). Engines of creation: The coming era of Nanotechnology. Doubleday.

Drexler, K. E. (1992). Nanosystems: Molecular machinery, manufacturing, and computation. Wiley.

Elbaraasi, H., Mezes, M., Balogh, K., Horvath, L., \& Csengeri, I. (2004). Effects of Dietary ascorbic acid/iron on some production traits, lipid peroxide state and amount/activity of the gluthione redox system in African Catfish Clarias gariepinus (Burchell) fingerlings. Aquatic Sciences and Fisheries Abstracts, 35(3), 256-262.

Fasakin E. A., Balogun A. M., \& Daramola A. G. (2003). A linear programming approach to low-cost fish feed formulation using water fern and duckweed as protein source. In 14th annual national conference of fisheries society of Nigeria (pp. 19-23) January, 1998, Ibadan, Nigeria.

FAO. (2019). Food and Agricultural Organisation of the United Nations: The state of world fisheries and Aquaculture Rome, Italy.

Gbadamosi, O. K. (2006). Evaluation of dietary ascorbic acid supplementation in practical diets for African Catfish Clarias gariepinus (Burchell 1822) Fingerlings. An M. Tech thesis submitted to the department of Fisheries and Wildlife, Federal University of Technology, Akure, Ondo State (pp. 13-107).

Gbadamosi, O. K., Fasakin, E. A., \& Adebayo, O. T. (2017). Hyperthermal-induced stress effects on survival and expression of heat shock protein (HSP) genes in Nile tilapia, Oreochromis niloticus fingerlings fed aqueous extract from Moringa oleifera leaf. Livestock Research for Rural Development, 29(4), 19-28.

Gieseker, C., Serfling, S. G., \& Reimschuessel, R. (2006). Formalin treatment to reduce mortality associated with Saprolegnia parasitica in rainbow trout, Oncorhynchus mykiss. Aquaculture, 253(2006), 120-129.

Grant, G. H., Silverman, L. M., \& Christenson, R. H. (1987). Amino acids and proteins (3rd ed.). WB Saunders Company.

Hardy, R. W., \& Sullivan, C. V. (2003). Pathogenesis of infectious diseases of fish. Annual Review of Microbiology, 40, 479-502.

Huber, D. L. (2005). Synthesis, properties, and applications of iron nanoparticles. Small (Weinheim an Der Bergstrasse, Germany), 1, 482-501.
Leonor, G., \& Rui, F. O. (2009). Psychological stress and welfare in fish. Annual Review of Biomedical Sciences., 11, 1-20.

Lynch, S. R. \& Cook, J. D. (1980). Interaction of vitamin C and Iron. Annals New York Academy of Sciences, 1-13.

Merchie, G., Lavens, P., \& Sorgeloos, P. (1997). Optimization of dietary vitamin C in fish and crustacean larvae: A review. Aquaculture, 155, 165-181.

Naoya, K., Hiroyuki, H., Takeshi, K., \& Kazuhiro, N. (2014). Psychological stress activates a dorsomedial hypothalamus-medullary raphe circuit driving brown adipose tissue thermogenesis and hyperthermia. Cell Metabolism. https://doi.org/10.1016/j.cmet.2014.05.018

Saima, R., Adnan, H. G., Irshad, A., \& Sheikh, I. R. (2017). Stress in aquaculture hatcheries: Source, impact and mitigation. International Journal of Current Microbiology and Applied Sciences., 6(10), 3030-3045.

Sen, S. S., Giri, S. S., \& Sukumaran, V. (2014). Role of HSP70 in cytoplasm protection against thermal stress in rohu, Labeo rohita. Fish and Shellfish Immunology, 41, 294-299.

Svobodova, Z., Pravda, D. \& Palackova, J. (1991). Unified methods of haematological examination of fish. Vodary, Czechoslovakia. Research unit of fish culture and hydrobiology.

Tejpal, C. S., Pal, A. K., Sahu, N. P., Kumar, J., Muthappa, N. A., Vidya, S., \& Rajan, M. G. (2009). Dietary supplementation of L-tryptophan mitigates crowding stress and augments the growth in Cirrhinus mrigala fingerlings. Aquaculture, 293, 272-277.

Tekle, E. W., \& Sahu, N. P. (2015). Growth and immunodulatory response of Nile tilapia, Oreochromis niloticus fingerlings to ethanolic extract of Moringa oleifera flower. International Journal of Sustainable and Renewable Products, 5(7), 285-296.

Zhang, W. X. (2003). Nanoscale iron particles for environmental remediation: An overview. Journal of Nanoparticle Research., 5(34), 323-332.

\section{Publisher's Note}

Springer Nature remains neutral with regard to jurisdictional claims in published maps and institutional affiliations.

\section{Submit your manuscript to a SpringerOpen ${ }^{\circ}$ journal and benefit from:}

- Convenient online submission

- Rigorous peer review

- Open access: articles freely available online

- High visibility within the field

- Retaining the copyright to your article

Submit your next manuscript at $>$ springeropen.com 